\title{
Chapter 7 \\ Autonomous Adaptation to Flooding \\ by Farmers in Pakistan
}

\author{
Ajaz Ahmed
}

\section{Key Messages}

- Farmers in Pakistan are very vulnerable to the impacts of natural hazards such as floods and droughts.

- Farm households in northern Pakistan use autonomous adaptations to adjust to monsoon flooding.

- Farm households' vulnerability, their knowledge of adaptation options and expected benefits, and prior experience with adaptation motivate the uptake of adaptation.

\subsection{Introduction}

Pakistan has faced increasing frequency of natural disasters such as floods and droughts in the past few decades due to its vulnerability to climatic changes (Abid et al., 2016; Ullah et al., 2019). In the 2020 Global Climate Risk Index report, Pakistan ranks 5th among the 10 countries most affected by natural hazards from 1999 to 2018 (Eckstein et al., 2020). Climate projections indicate a further increase in temperature by $2^{\circ}-3^{\circ}$ and a significant variation in the distribution of rainfall in Pakistan by 2050 (Gorst et al., ). Pakistan is not only among the world's regions that are highly prone to climate change-induced natural disasters (Ullah et al., 2019), it has also sustained greater damage because of its low adaptive capacity (Stocker et al., 2013).

According to 2017 population census, roughly 64\% of the population of Pakistan resides in rural areas and is predominantly involved in agriculture. The sector, which contributes $20 \%$ to the country's total GDP and employs $43 \%$ of its workforce (Ali \& Erenstein, 2017; Jamshed et al., 2019), is also highly vulnerable to natural hazards

\footnotetext{
A. Ahmed ( $\bigotimes)$

Institute of Business Administration, Karachi, Pakistan

e-mail: ajazahmeda23@gmail.com
} 
that are intensifying due to climate change (Abid et al., 2015; Ali \& Erenstein, 2017; Bakhsh \& Kamran, 2019; Ullah et al., 2019). The resulting crop failure causes loss of livelihood and damage to agricultural investment (Jamshed et al., 2019; Ullah et al., 2019) and the impact on staple food crops threatens food security (Bakhsh \& Kamran, 2019).

Unfortunately, the situation is exacerbated by the fact that relatively poorer populations tend to reside in the most flood-prone rural areas (Qasim et al., 2015; Rana \& Routray, 2016) with limited access to off-farm income opportunities, skills, and basic amenities (Deen, 2013).

While the frequency of natural hazards has gradually increased in Pakistan (Wester et al., 2019), monsoon floods occur almost annually (Ahmad and Ma, 2020; Jamshed et al., 2019; Rana \& Routray, 2016) causing substantial damage to the Pakistani economy (Rana \& Routray, 2016). However, the government response to monsoon flooding has been both inadequate and inefficient owing to a lack of resources, reactive planning, focus on post-disaster relief, poor coordination between the responsible agencies, the absence of local-level disaster preparedness, and a lack of community involvement (Ahmad et al., 2019; Deen, 2013; GoP, 2016; Rahman \& Khan, 2011). This is also because government investments have prioritized urban infrastructure to support the increasing urban population and industrial activities (Bakhsh \& Kamran, 2019).

Since roughly two-thirds of the country's population reside in rural areas and relies on agriculture, it is vital to develop rural farming communities' resilience to the climate change-driven monsoon floods using farm level adaptation measures (Ali \& Erenstein, 2017; Bakhsh \& Kamran, 2019) which can increase food security. Until now the use of farm-level adaptation measures has, however, been very limitedmainly due to a lack of knowledge and resources (Abid et al., 2015, 2016; Ahmad et al., 2019; Rauf et al., 2017).

Farm households in Pakistan have used various adaptation measures such as structural modifications to buildings and savings as precautionary measures in response to floods (Shah et al., 2017). Other measures include changes in crop varieties introducing more diversification (Adnan \& Lohano, 2022, Chap. 28 of this volume) and drought-resistant varieties; changes in use of fertilizer and manure use; plowing methods; planting trees, changes in date of sowing; off-farm income participation and crop-livestock interaction; changes in water management; off-farm employment, consumption smoothing, credit, and migration in response to drought (Abid et al., 2015, 2016; Ali \& Erenstein, 2017; Ashraf \& Routray, 2013; Bakhsh \& Kamran, 2019; Rahut \& Ali, 2017; Ullah et al., 2019). Using traditional crop varieties (Tshotsho, 2022, Chap. 6 of this volume) and providing seasonal agro-met advisories (Manjula et al., 2021, Chap. 18 of this chapter) are additional methods of prompting climate change adaptation.

This research uses a primary survey and binary logistic regression to investigate the factors explaining farm household decisions in Nowshera district to invest in various adaptation measures in response to flooding. Located in the Khyber Pakhtunkhwa province in northern Pakistan, Nowshera is subject to monsoon flooding due to its proximity to the Kabul River (Ahmad et al., 2011; Khan et al., 2013). The results of 
this study will help in understanding the nature of autonomous adaptation measures uncovering the drivers and constraints.

\subsection{Study Context and Data}

Nowshera is an agricultural district with limited off-farm income opportunities and the majority of the population is involved in agriculture for food, fodder, and livelihood. The main crops are maize, wheat, barley, tobacco, and sugarcane; however, some farmers also grow vegetables on a commercial scale.

Floods are a big risk to farming, causing crop failure and loss of livelihood in addition to damages to housing and infrastructure. The fundamental assumption is that rational farmers will use flood adaptation strategies to mitigate the flood damages.

\subsubsection{Identification of Adaptation Options}

The selection of adaptation options for this study was done following three steps. The first step involved the survey of literature on flood adaptation measures being used in developing countries to prepare a broad list of adaptations. This was followed by focus group discussions (FGDs) with the District Agriculture Office and Field Extension Office to shortlist the most likely adaptation options. In the third step, floodaffected farm households were consulted, and they confirmed the use of two adaptation options. The first adaptation option is the elevated ground floor, i.e., elevated base column of the ground floor, which helps reduce the exposure to flood water. The second adaptation measure is maintaining food stock (by storing surplus wheat) to avoid shortage in case of crop failure. The use of both adaptation options has been reported in previous research (Shah et al., 2017).

\subsubsection{Data Collection}

A multistage sampling approach was adopted to select representative households. Initially, three flood-affected and two non-affected union councils ${ }^{1}$ were selected from the total of 27 flood-affected and 20 non-affected union councils using secondary information provided by the local Field Extension Office. After this,

\footnotetext{
${ }^{1}$ A union council forms the third tier of local government, after district and tehsil, within a province in Pakistan. Size of the union council varies from district to district.
} 
homogenous villages from both subpopulations were identified. Lastly, the households were sampled considering their distance to the river, farm size ${ }^{2}$ and their location in five zones along the Kabul River, to account for spatial heterogeneity. The sample size of this study is 500 farm households, 300 of which belonged to flood-affected villages and 200 to non-flood-affected villages. A pilot questionnaire containing questions on household socioeconomic characteristics, flooding, agricultural practices, and other pertinent information was used to collect the data. The survey was administered by a team of trained enumerators who conducted supervised face-to-face interviews in Pashto, the local language.

\subsubsection{Data Analysis}

Descriptive analysis is used to present the information on flood impact, i.e., damages, and adaptation uptake, whereas empirical analysis is used to investigate the factors affecting farm households' flood adaptations. Empirical analysis is conducted using a binary logistic regression as it is an appropriate technique for a dichotomous choicedependent variable (0/1). Two different regression models have been estimated to explore the drivers of uptake of each adaptation option. Each dependent variable in the regression is a dummy variable, where one is assigned a household, who adopted specific measure and zero otherwise. Adaptation uptake is a dichotomous choice that means adaptation or no adaptation. The underlying assumption is that farm households that adapt perceive adaptation as a risk reduction mechanism and thus beneficial in the face of floods. However, the farm households that do not adapt refrain from doing so maybe due to their personal conditions and various socioeconomic constraints.

\subsection{Descriptive Results}

\subsubsection{Flood Impacts}

Monsoon floods in Nowshera have a negative impact on crops, livestock, farmhouse infrastructure, and local businesses. As discussed in Aftab et al. (2021), data shows that in the last main flood about $60 \%$ households suffered crop damage, $28 \%$ reported damage to their farmhouses, $11 \%$ farm households lost their livestock, and $1 \%$ farm households reported damage to their businesses. Farmhouse infrastructure includes roofed spaces for livestock, storage, and farm machinery. The reported monetary value of average losses per household in Nowshera in the last main flood is 193,770 Pakistani rupees (PKRs) (1206.21 USD) for crops, PKRs 111,660 (695.138 USD)

\footnotetext{
${ }^{2}$ Small and large farms were categorized depending on whether they were below or above 1 ha, respectively.
} 
Table 7.1 Flood damages and their monetary value

\begin{tabular}{l|l|c}
\hline Damages & $\begin{array}{l}\text { Affected } \\
\text { households (\%) }\end{array}$ & $\begin{array}{l}\text { Average monetary } \\
\text { value (PKRs) (USDs) }\end{array}$ \\
\hline Crops & 60 & $193,770(1206.21)$ \\
\hline $\begin{array}{l}\text { Farm housing } \\
\text { infrastructure }\end{array}$ & 28 & $111,660(695.138)$ \\
\hline Livestock & 11 & $91,650(570.536)$ \\
\hline Local businesses & 1 & $101,750(633.387)$ \\
\hline
\end{tabular}

Source Field data

Table 7.2 Basic services disruption and restoration time

\begin{tabular}{l|l|l}
\hline $\begin{array}{l}\text { Disrupted } \\
\text { services }\end{array}$ & $\begin{array}{l}\text { Affected } \\
\text { households (\%) }\end{array}$ & $\begin{array}{l}\text { Restoration time } \\
\text { (months) }\end{array}$ \\
\hline Water supply & 56 & 5 \\
\hline Electricity & 95 & 6 \\
\hline $\begin{array}{l}\text { Transport } \\
\text { infrastructure }\end{array}$ & 94 & 7 \\
\hline Health service & 94 & 7 \\
\hline
\end{tabular}

Source Field data

for damage to the housing infrastructure, PKRs 91,650 (570.536 USD) for livestock losses and PKRs 101,750 (633.387 USD) for business losses (see Table 7.1). These households are heavily reliant on farming for their livelihood and often do not have access to financial instruments such as loans or other income support. Since agriculture is the main source of livelihood, fewer households have suffered from business enterprise losses.

It is not just the farm households which have sustained flood damages, but flooding has also disrupted the supply of basic public services such as water, electricity, transport, and health in Nowshera. Survey responses show that roughly $56 \%$ of households lost access to domestic potable water and more than $90 \%$ reported that transportation and health and electricity services were disrupted during the last big flood. The minimum time to restore the basic services was anywhere between 5 and 7 months (see Table 7.2).

\subsubsection{Flood Adaptations Uptake}

As indicated in Aftab et al. (2021), about $45 \%$ of flood-affected farm households use an elevated ground floor to reduce the exposure to flood water. This is indisputably a flood adaptation as it is only reported in the flood-affected sample households. The maintenance of food stock, which has other benefits as well, is being used in both the flood-affected and non-affected samples. However, the use of food stock is $16 \%$ higher in the flood-affected areas which shows that it is clearly also an adaptation to 
monsoons floods. This is similar to the consumption smoothing adaptation reported in climate adaptation literature (Ashraf \& Routray, 2013).

\subsection{Empirical Results}

Empirical results of factors affecting the uptake of flood adaptations strategies using binary logistic regression technique are presented in Table 7.3. The independent variables used in two estimated models include farm household sociodemographic characteristics, farming-related information, and institutional features. Marginal effects are presented for the ease of interpretation which shows the probability of implementing each adaptation option in percentage terms. The main results that regression analysis has uncovered in this research are divided into three contentions. First, the adaptation process is influenced by the known vulnerability of agents. Second, knowledge of adaptation options and expected benefits drive the adaptation uptake. Third, learning from the past such as prior experience with adaptation needs and their benefits motivates the uptake of adaptation. Each of the three arguments is contextualized below using the results of this research.

Table 7.3 Binary logistic estimates of factors affecting the adaptation decision

\begin{tabular}{|c|c|c|}
\hline \multirow[t]{2}{*}{ Variables } & \multicolumn{2}{|l|}{ Margins } \\
\hline & Elevated ground floor & Food stock \\
\hline \multirow[t]{2}{*}{ Off-farm work } & -0.036 & -0.075 \\
\hline & $(2.02)^{*}$ & $(3.49)^{* *}$ \\
\hline \multirow[t]{2}{*}{ Agriculture extension } & 0.068 & 0.070 \\
\hline & $(2.03)^{*}$ & $(1.58)$ \\
\hline \multirow[t]{2}{*}{ Farm to river distance } & -0.059 & 0.084 \\
\hline & $(4.88)^{* *}$ & $(5.80)^{* *}$ \\
\hline \multirow[t]{2}{*}{ Flood inundation } & 0.182 & - \\
\hline & $(4.08)^{* *}$ & - \\
\hline \multirow[t]{2}{*}{ Flood duration } & - & 0.019 \\
\hline & - & $(3.18)^{* *}$ \\
\hline \multirow[t]{2}{*}{ Farming experience } & - & 0.004 \\
\hline & - & $(2.46)^{*}$ \\
\hline \multirow[t]{2}{*}{ Tribal diversity } & 0.013 & - \\
\hline & $(2.14)^{*}$ & - \\
\hline \multirow[t]{2}{*}{ Flood-affected villages } & - & 0.648 \\
\hline & - & $(5.89)^{* *}$ \\
\hline
\end{tabular}

Source Field data

$* * * \mathrm{p}<0.01, * * \mathrm{p}<0.05, * \mathrm{p}<0.1$ 
While the aforementioned three arguments enrich the results' discussion, they are also supported by the findings of Aftab et al. (2021). Furthermore, unlike the analysis in Aftab et al. (2021), this chapter reports two regression models.

\subsubsection{Difference in Known Vulnerability}

Empirical results of this research have clearly indicated that adaptation is moderated by the difference in vulnerability of the flood-affected communities. For example, findings show that farm households with more family members working off-farm are less likely to elevate the building ground floor or stock the food (Table 7.3). The most plausible interpretation of this result is that perhaps farm households with additional sources of income are more resilient and less vulnerable to the impact of floods. Results show that each additional off-farm worker reduces the farm households' likelihood to elevate the ground floor by roughly 4\%. Likewise, an additional offfarm household worker reduces the farm households' probability of keeping the stock of food by about $8 \%$.

Findings reveal that the greater the area of land of a farm household inundated in the last flood the more likely it is that the household will elevate the ground floor of the house. The chances of the use of elevated ground floor as an adaptation to flooding increases by nearly $18 \%$ with every additional hectare of inundated land. On the other hand, the further a farm household is from the river, the lower the chances of elevating the ground floor of the house. Each additional kilometer of distance from the river reduces the farm household's probability of elevating the ground floor by about $6 \%$. Findings are comparable with the results of Mulwa et al. (2017), Choloet al. (2018), Boansi et al. (2017) and Tessema et al. (2019) studies.

Another variable which shows the difference in vulnerability and thereby the adoption of adaptations among farm households in the study area is the flood-affected dummy variable which is used to differentiate the uptake of food stock between flood-affected and non-affected villages. Results show that flood-affected villages have almost $65 \%$ higher probability to use food stock than non-affected villages.

\subsubsection{Knowledge and Communal Learning}

Findings of this research support the contention that knowledge drives adaptation uptake. Findings reveal that farm households with access to agricultural extension services have a $7 \%$ higher likelihood of elevating the ground floor of their houses. Access to agricultural extension services has an almost equal contribution in the uptake of food stock as in adaptation to flooding. These findings are also consistent with previous studies such as Nhemachena and Hassan, (2007), Mulwa et al. (2017), Boansi et al. (2017), Tessema et al. (2019), and Bedeke et al. (2019). 
Interestingly, tribal diversity has a positive correlation with the use of elevated ground floor, which suggests that farm households from villages with more tribal diversity have a higher uptake of an elevated ground floor as an adaptation option. It is reasonable to believe that villages with more tribal diversity have greater communal learning among the farm households in study areas. This also signifies the role of tribal diversity, and hence intertribal competition in the adoption of agricultural technologies that provides a safety net as well as comparative advantage in rural tribal societies such as in district Nowshera.

\subsubsection{Learning from the Past}

It is a well-established fact that past experience helps communities in dealing with disasters, for example, farmer experience is always a significant driver for adoption of different farming practices. However, this research reveals that farmer experience is even more crucial owing to low literacy and education and the limited role of agricultural extension. Results show that farming experience is positively correlated with food stock as an adaptation to monsoon flooding in Nowshera, signifying that farm households with greater farming experience are more likely to use food stock as an adaptation to monsoon flooding. It is plausible that farmers with greater experience have faced multiple shocks; including unfavorable weather conditions for farming and thereby their livelihood. Hence, they have a higher tendency to adapt than their counterparts with less farming experience.

A similar result shows that flood duration has a positive correlation with food stock, indicating that households which have experienced longer floods in the past are more likely to stock the food as an adaptation to floods. Each additional day of standing flood water stood in the last flood increases the likelihood that a farm household stocks food by about $2 \%$. These results indicate that prior knowledge and experience play a vital role in the adaptation process.

\subsection{Conclusion and Policy Implications}

This study investigates farm households' autonomous adaptation to monsoon flooding using a primary survey of 500 flood-affected and non-affected farm households in one flood-affected district, i.e., Nowshera, in northern Pakistan. It uses binary logistic regression technique to analyze farm households' autonomous adaptation to monsoon flooding.

The findings reveal that monsoon flooding in Nowshera caused damage to crop, livestock, farm housing infrastructure, and local businesses in addition to disrupting the supply of basic public services such as water, electricity, transport, and health in the last major flood. Unfortunately, government departments took long to restore the supply of basic services which had a very negative impact on the resilience of 
the flood-affected communities. Timely restoration of basic gateway services could facilitate normalcy and reduce the bounce back time for flood-affected communities. Survey data shows that farm households in the study area use elevated ground floor and food stock as autonomous adaptation measures to adapt to the monsoon floods. While food stock is also used in non-affected areas, it is an adaptation in floodaffected villages. Evidently, farm households' adoption of autonomous adaptations indicates that they understand flood risks and are willing to make investment in resilience building measures. This indicates that farm households would be willing to adopt the policy interventions initiated to manage the flood risk. Findings of this research show that the adaptation process in study areas is moderated by three key phenomena.

First, it is the difference in known vulnerability that enables farm households to adapt to the monsoon flooding. For example, off-farm work has a negative correlation with both adaptation options, elevated ground floor and food stock, which suggests that farm households with multiple sources of income have better adaptive capacity, and hence better resilience to the floods. The policy implication of this result is that livelihood diversification can reduce the farm households' risk from flooding. The role of farm to river distance in the decision to implement flood adaptation implies that flood impact has a spatial aspect and the interventions including post-flood support should be designed considering the location of the communities, their chances of exposure, and the level of risk.

Second, knowledge and communal learning supports the adaptation process in study areas. For example, access to agricultural extension services has a positive role in farm households' decision to elevate the ground floor of their houses to mitigate potential damages from future flood. This is an important result which shows that effective delivery of agricultural extension service has the potential to increase farmers' resilience to flooding. Interestingly, tribal diversity has a positive role in farm households' uptake of adaptation in study areas which is possibly due to communal learning. This indicates that there is a social dimension to adoption of technologies that provides an economic safety net to vulnerable farm households in rural and tribal settings. Hence, policymakers must take this into account while designing disaster risk management policies and strategies.

Third, farm households' prior experience informs their adaptation decisions. Findings show that flood inundation, flood duration, and farming experience are positively correlated with the decision to implement flood adaptations. These factors allow policymakers to distinguish between households, target adaptation incentives, and implement activities while considering households' risk perceptions and their prior experience with flooding and farming practices.

This research has unveiled that there is a suboptimal use of autonomous flood adaptation measures in flood-affected villages as farm households have not exploited the full potential of available autonomous adaptation. While some adaptation options have limited uptake, others have not been explored at all. For instance, hardly any households in the study areas grow short duration crops that are suited to flooding. The findings highlight the need to facilitate and encourage flood adaptations through a program of agriculture extension services and other soft interventions. 
Acknowledgements This research was funded by the South Asian Network for Development and Environmental Economics (SANDEE), Nepal and partial results of the survey reported in this study have been published in Aftab et al. (2021). I am thankful to SANDEE for their financial and technical support without which this research would not be possible.

\section{References}

Abid, M., Scheffran, J., Schneider, U. A., \& Ashfaq, M. (2015). Farmers' perception of an adaptation strategies to climate change and their determinants: The case of Punjab Province, Pakistan. Earth System Dynamics, 6, 225-243.

Abid, M., Schneider, U. A., \& Scheffran, J. (2016). Adaptation to climate change and its impacts on food productivity and crop income: Perspectives of farmers in rural Pakistan. Journal of Rural Studies, 47, 254-266.

Adnan, N., \& Lohano, H. D. (2022). Resilience through Crop diversification in Pakistan. In A. K. E. Haque, P. Mukhopadhyay, M. Nepal, \& M. R. Shammin (Eds.), Climate change and community resilience: Insights from South Asia (pp. 431-442). Springer.

Aftab, A., Ahmed, A., \& Sacrpa, R. (2021). Farm households perception of weather change and flood adaptations in Northern Pakistan. Ecological Economics, 182, 106882.

Ahmad, D., Afzal, M., \& Rauf, A. (2019). Analysis of wheat farmers' risk perceptions and attitudes: Evidence from Punjab, Pakistan. Natural Hazards, 95(3), 845-861.

Ahmad, F., Kazmi, S. F., \& Pervez, T. (2011). Human response to hydro-meteorological disasters: A case study of the 2010 flash floods in Pakistan. Journal of Geography Regional Planning, 4(9), $518-524$.

Ali, A., \& Erenstein, O. (2017). Assessing farmer use of climate change adaptation practices and impacts on food security and poverty in Pakistan. Climate Risk Management, 16, 183-194.

Ashraf, M., \& Routray, J. K. (2013). Perception and understanding of drought and coping strategies of farming households in north-west Balochistan. International Journal of Disaster Risk Reduction, 5, 49-60.

Bakhsh, K., \& Kamran, M. A. (2019). Adaptation to climate change in rain-fed farming system in Punjab, Pakistan. International Journal of the Commons, 13(2), 833-847.

Bedeke, S., Vanhove, W., Gezahegn, M., Natarajan, K., \& Damme, P. V. (2019). Adoption of climate change adaptation strategies by maize-dependent smallholders in Ethiopia. NJAS-Wageningen Journal of Life Sciences, 88, 96-104.

Boansi, D., Tambo, J. A., \& Müller, M. (2017). Analysis of farmers' adaptation to weather extremes in West African Sudan Savanna. Weather and Climate Extremes, 16, 1-13.

Cholo, T., Fleskens, L., Sietz, D., \& Peerlings, J. (2018). Is Land fragmentation facilitating or obstructing adoption of climate adaptation measures in Ethiopia? Sustainability, 10, 2120.

Deen, S. (2013). Pakistan 2010 floods. Policy gaps in disaster preparedness and response. International Journal of Disaster Risk Reduction, 12, 341-349.

Eckstein, D., Künzel, V., Schäfer, L., \& Winges, M. (2020). Global climate risk index 2020 who suffers most from extreme weather events? Weather-related loss events in 2018 and 1999 to 2018. Briefing Paper, German Watch.

Gorst, A., Groom, B., \& Dehlavi, A. (2015). Crop productivity and adaptation to climate change in Pakistan. Centre for climate change economics and policy. Working paper No. 214.

Government of Pakistan. (2016). Annual flood report 2016. Federal Flood Commission, Ministry of Water and Power, Government of Pakistan.

Jamshed, A., Rana, I. A., Mirza, U. M., \& Birkmann, J. (2019). Assessing relationship between vulnerability and capacity: An empirical study on rural flooding in Pakistan. International Journal of Disaster Risk Reduction, 36, 101109. 
Khan, A. N., Khan, B., Qasim, S., \& Khan, S. N. (2013). Causes, effects and remedies: A case study of rural flooding in district Charsadda, Pakistan. Journal of Management Science, VII $(1,2)$.

Manjula, M., Rengalakshmi, R., \& Devaraj, M. (2021). Using Climate information for building small holder resilience in India. In A. K. E. Haque, P. Mukhopadhyay, M. Nepal, \& M. R. Shammin (Eds.), Climate change and community resilience: Insights from South Asia (pp. 275289). Springer.

Mulwa, C., Marenya, P., Rahut, D. B., \& Kassie, M. (2017). Response to climate risks among smallholder farmers in Malawi: A multivariate probit assessment of the role of information, household demographics, and farm characteristics. Climate Risk Management 16208-16221.

Nhemachena, C., \& Hassan, R. (2007). Micro-level analysis of farmers' adaptation to climate change in Southern Africa. IFPRI Discussion Paper No. 00714. International Food Policy Research Institute.

Qasim, S., Khan, A. N., Shrestha, R. P., \& Qasim, M. (2015). Risk perception of the people in the flood prone Khyber Pukhthunkhwa province of Pakistan. International Journal of Disaster Risk Reduction, 14, 373-378.

Rahman, A. U., Khan, A. N. (2011) Analysis of flood causes and associated socioeconomic damages in the Hindukush region. Nature Hazards, 59, 1239-1260

Rahut, D. B., \& Ali, A. (2017). Coping with climate change and its impact on productivity, income, and poverty: Evidence from the Himalayan region of Pakistan. International Journal of Disaster Risk Reduction, 24, 515-525.

Rana, I. A., \& Routray, J. K. (2016). Actual vis-à-vis perceived risk of flood prone urban communities in Pakistan. International Journal of Disaster Risk Reduction, 19, 366-378.

Rauf, S., Bakhsh, K., Abbas, A., Hassan, S., Ali, A., \& Kächele, H. (2017). How hard they hit? Perception, adaptation and public health implications of heat waves in urban and peri-urban Pakistan. Environmental Science and Pollution Research, 24(11), 10630-10639.

Shah, A. A., Ye, J., Abid, M., \& Ullah, R. (2017). Determinants of flood risk mitigation strategies at household level: A case of Khyber Pakhtunkhwa (KP) province, Pakistan. Natural Hazards, $88,415-430$.

Stocker, T. F., Dahe, Q., \& Plattne, G. (2013). Climate change 2013: The physical science basis. Working Group-I contribution to the fifth assessment report of the intergovernmental panel on climate change. Summary for Policymakers.

Tessema, Y. A., Joerin, J., \& Patt, A. (2019). Climate change as a motivating factor for farmadjustments: Rethinking the link. Climate Risk Management, 23, 136-145.

Tshotsho. (2022). Indigenous practices of paddy growers in Bhutan: A safety net against climate change. In A. K. E. Haque, P. Mukhopadhyay, M. Nepal, \& M. R. Shammin (Eds.), Climate change and community resilience: Insights from South Asia (pp. 87-100). Springer.

Ullah, W., Nafees, M., Khurshid, M., \& Nihei, T. (2019). Assessing farmers' perspectives on climate change for effective farm-level adaptation measures in Khyber Pakhtunkhwa, Pakistan. Environmental Monitoring and Assessment, 191, 547.

Wester, P., Mishra, A., Mukherji, A., \& Shrestha, A. B. (Eds.). (2019). The HinduKush Himalaya assessment-Mountains, climate change, sustainability and people. Springer Nature Switzerland AG. 
Open Access This chapter is licensed under the terms of the Creative Commons AttributionNonCommercial-NoDerivatives 4.0 International License (http://creativecommons.org/licenses/bync-nd/4.0/), which permits any noncommercial use, sharing, distribution and reproduction in any medium or format, as long as you give appropriate credit to the original author(s) and the source, provide a link to the Creative Commons licence and indicate if you modified the licensed material. You do not have permission under this licence to share adapted material derived from this chapter or parts of it.

The images or other third party material in this chapter are included in the chapter's Creative Commons licence, unless indicated otherwise in a credit line to the material. If material is not included in the chapter's Creative Commons licence and your intended use is not permitted by statutory regulation or exceeds the permitted use, you will need to obtain permission directly from the copyright holder.

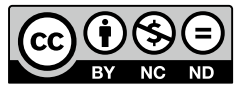

